\title{
Effects of Curing and Cement Type on Leak deterioration of Concrete in Water Tanks
}

\section{Matiwos Tsegaye ${ }^{1 *}$ and Abebe Dinku}

${ }^{1}$ Department of Civil Engineering, Amhara Construction Design and Supervision Enterprise, Bahir Dar, Ethiopia

${ }^{2}$ Department of Civil Engineering, School of Civil and Environmental Engineering, Chair of Construction Materials and Management, Addis Ababa Institute of Technology, Addis Ababa, Ethiopia

\begin{abstract}
Premature-deterioration of concrete in water storage tanks is a common problem in Ethiopia. The research aims at evaluating the effects of cement-types and wet-curing period on the resistance of concrete to leaching and leakage, based on compression, water absorption, and acid attack tests. To meet this objective, 54 concrete specimens with a grade of C-30 and water to cement ratio of 0.53 were casted in to two groups, each subjected to $3,7,10$, and 28 days wet curing. The first group comprised 27 cubes made from OPC, while the second made from PPC. ANOVA was employed to test significances of variables on sorptivity. The sorptivity was higher for PPC than OPC for 10days and below cured specimens; however, well cured PPC exhibited better sorptivity per- formance at age of 58 and 98 days. ANOVA indicated that well-cured specimens made using PPC had significantly showed lower sorptivity than OPC age of 98 days. The resistance to acid attack of PPC was better than OPC. The finding showed that the selection of well cured-OPC and 10 days cured-PPC for concrete water tanks could be the cause for deterioration associated with leaching and leakage in concrete water retaining structures. The study contributes to the design of water storage structures.
\end{abstract}

Keywords: Cement; Curing; Deterioration; Leaching; Leakage; Sorptivity; Sulfuric acid

Abbreviations: ANOVA: Analysis of Variance and Covariance; DOE: Department of Environment; D: Day; FA: Fly Ash; G: Gram; OPC: Ordinary Portland Cement; PPC: Portland Pozzolana Cement; RC: Reinforced Concrete; SF: Silica Fume; S: Sorptivity

\section{Introduction}

Water retaining concrete structures must be built as impermeable and watertight in order to avoid water loss and to ensure durability of concrete [1]. Although the maximum permissible crack width formed during dry shrinkage is designed to be controlled by reinforcement bar, the water tightness of the RC water tank is in question as leaching and wick action can take place in a concrete with low porosity and permeability. The deterioration of concrete involves movement of aggressive gases and/or liquid from surrounding environment into concrete followed by physical and/or chemical reaction within its internal structure [2]. The transport of water in unsaturated concrete exposed to water in one face depend on capillary suction [3], and wick action which is a combination of capillary suction in wet surface and evaporation in drying face [4]. For ground or elevated RC water storages subjected to wetting and drying cycle, the capillary suction force is responsible for ingress of water through the concrete. Therefore, flow of water driven by wick action accompanied with dissolution of solid material can lead to gradual deterioration of concrete in water storage structures.

Water tightness can be reduced as a progress of liquid accompanied by gradual dissolution (leaching) of cement hydrate. Thus, leaching is a deterioration mechanism of concrete in contact with water $[5,6]$. Leaching of lime increases both the porosity and permeability of the cement paste and this, in turn, causes a decrease in the water tightness of the concrete [7], and reduces mechanical properties [8-10]. The rise in porosity within concrete resulted from leaching increases the transport of fluid due to permeation, capillary suction, and diffusion. Evidently, Bentz and Garboczi [11] found that effective diffusivity coefficients increased by 40 due to total lime leaching from cement paste with w/c ratio of 0.5 . Thus, successive dissolution and transportation of hydration product can accelerate the deterioration of concrete in water storage structures as seen in Figure 1.
Cracks in concrete as a result of water evaporation can initially provide pathways for water penetration in concrete water retaining structures. In addition, the variation in level of water in the tank allows a chemical reaction by closing and opening the pores [12]. During low level of water, the pore allows intrusion of $\mathrm{CO}_{2}$ from atmosphere in to concrete. Evidently, leaching of $40 \%$ of lime was found to increased rate of carbonation by 1.45 [5]. Further, capillary force may cause acid to penetrate into concrete during wetting by suction while during drying, macro cracking can occur due to the accompanying shrinkage [13].

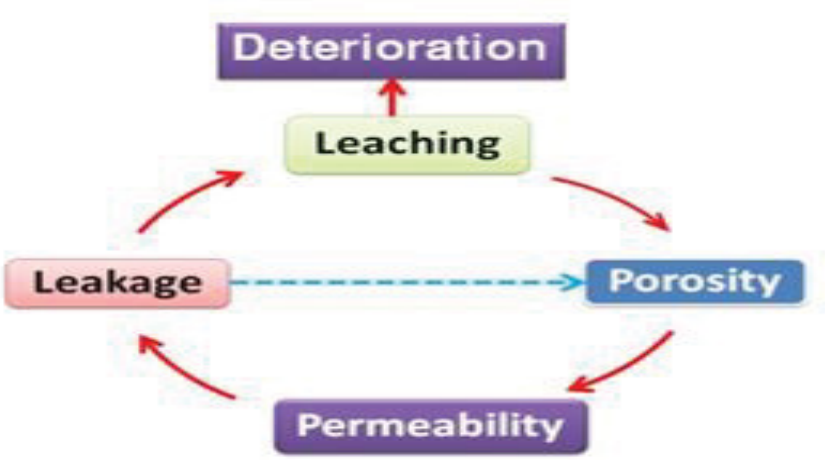

Figure 1: Cyclic process for leaching deterioration of concrete.

*Corresponding author: Matiwos Tsegaye, Senior Engineer, Department of Civil engineering, School of Civil and Environmental Engineering, Amhara Construction Design and Supervision Enterprise, Bahir Dar Ethiopia, Tel: (+251)-911-225896; E-mail:matiwostse@gmail.com

Received July 26, 2018; Accepted September 24, 2018; Published September 27, 2018

Citation: Tsegaye M, Dinku A (2018) Effects of Curing and Cement Type on Leak deterioration of Concrete in Water Tanks. J Civil Environ Eng 8: 322. doi: 10.4172/2165-784X.1000322

Copyright: () 2018 Tsegaye M, et al. This is an open-access article distributed under the terms of the Creative Commons Attribution License, which permits unrestricted use, distribution, and reproduction in any medium, provided the original author and source are credited. 
Citation: Tsegaye M, Dinku A (2018) Effects of Curing and Cement Type on Leak deterioration of Concrete in Water Tanks. J Civil Environ Eng 8: 322. doi: 10.4172/2165$784 \mathrm{X} .1000322$

Page 2 of 9

Rapid leaching process takes place when water percolates through the concrete due to pressure gradients because the water will reach much more internal area of soluble products and the dissolved material will be carried away by the flow of water downstream and out of the concrete [9]. The deformation in combined test (leaching and loading) accelerates a tertiary creep, leading to deterioration of concrete [14]. In addition to, the presence of damp surface due to leakage may favour for the growth green or dark coloured algae [15]. Deterioration of water tank seen in Figure 2 may be caused by the above mechanism as algae and dampness is appeared in the concrete wall.

\section{Significance of the study}

Inappropriate material selection and insufficient curing are of the known factors for durability of concrete that exposed to aggressive environment [16]. The research aim at evaluating the effects of cement type and wet curing period on the durability performance of concrete when it exposed to aggressive environment. Therefore, its significance relates to the design of reinforced concrete (RC) water storage tanks.

\section{Previous Studies}

\section{Effects of cement and curing}

Massazza [7] found that the sorptivity of mortar with a pozzolanic (CEM IV) was higher than OPC (CEM I) at the age of 28 days, however lower value was obtained after 90 days as shown in Table 1.

American Concrete Institution (ACI-308R 2008) [17] prescribed an extent of moist curing recommendations for various types of cement when experimental result is not available as presented in Table 2. The curing duration was determined at the age that the concrete can attain the $70 \%$ of specified compressive or flexural strength. The useful curing period for capillary segmentation was determined using interpolation from logarithm model developed from compressive strength results, and based on the follow-ups of the loss of mass of specimens placed in desiccative environment [18].

Bamforth [19] suggested that the coefficients of water permeability, and hence the durability of con- crete cannot be inferred from a measurement of strength without a detailed knowledge of the curing history. Thus, curing duration is more important than compressive strength result as shown in Figure 3. From this figure, the coefficients of permeability of 7-day cured concrete is approximately five times less than the 3-day cured for a compressive strength value of $30 \mathrm{MPa}$.

The concentration of $\mathrm{Ca}$ ion in $\mathrm{CH}$ is higher than in $\mathrm{CSH}$ gel, and the amount of $\mathrm{CH}$ in OPC is higher than pozzolan cement. Therefore, the volume of total dissolved solid will be higher for concrete made with OPC than pozzolan cement. Kamali et al. [20] found rate of degradation for OPC cement was higher as compared to mineral added cement in both pure water and acidic solution, as seen in Figure 4.

On other hand, OPC-concrete had showed highest mass loss among various cement types when it immersed to sulfuric acid solution for a period 12 weeks [21]. After 14-days im- mersion, the OPC concrete showed a highest value of $8.5 \%$ loss, while other cements fall below $8 \%$ as shown in Figure 5.
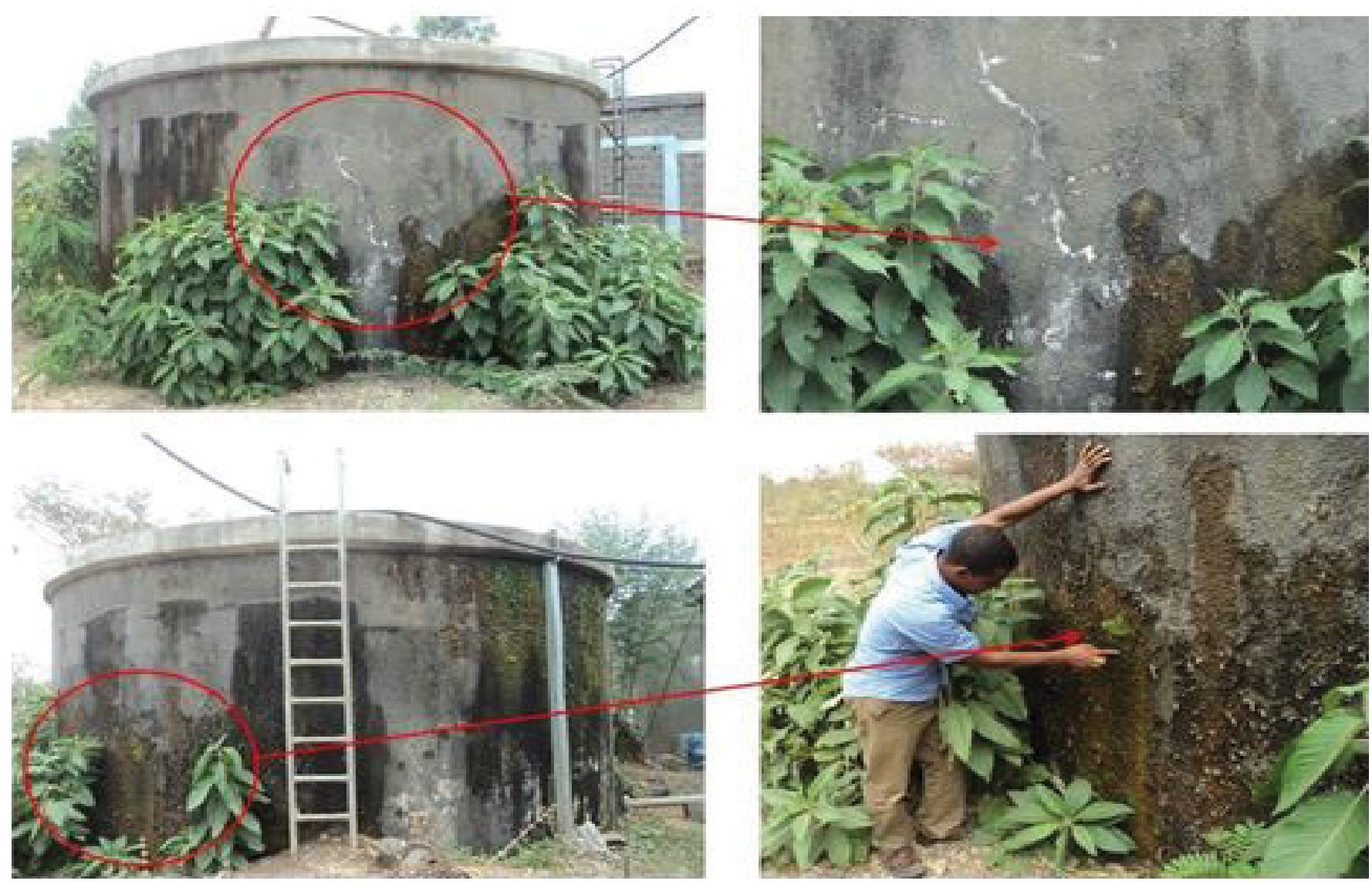

Figure 2: Surface deterioration of 15 years aged RC storage tank, Ethiopia (concrete made from Messobo OPC). 


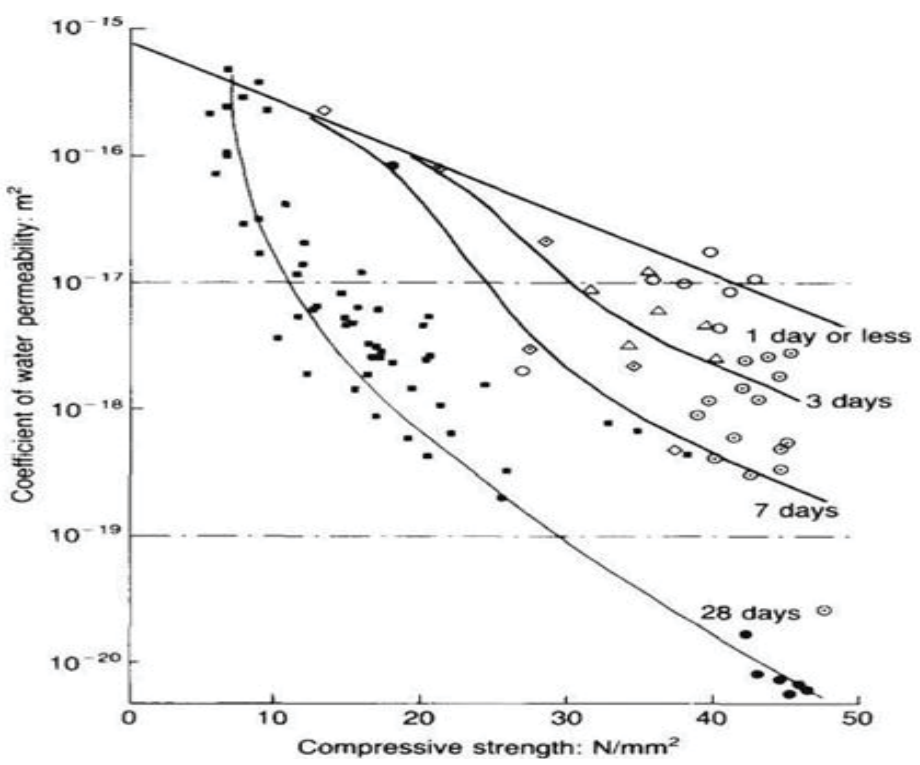

Figure 3: Compressive strength and permeability relation [19].
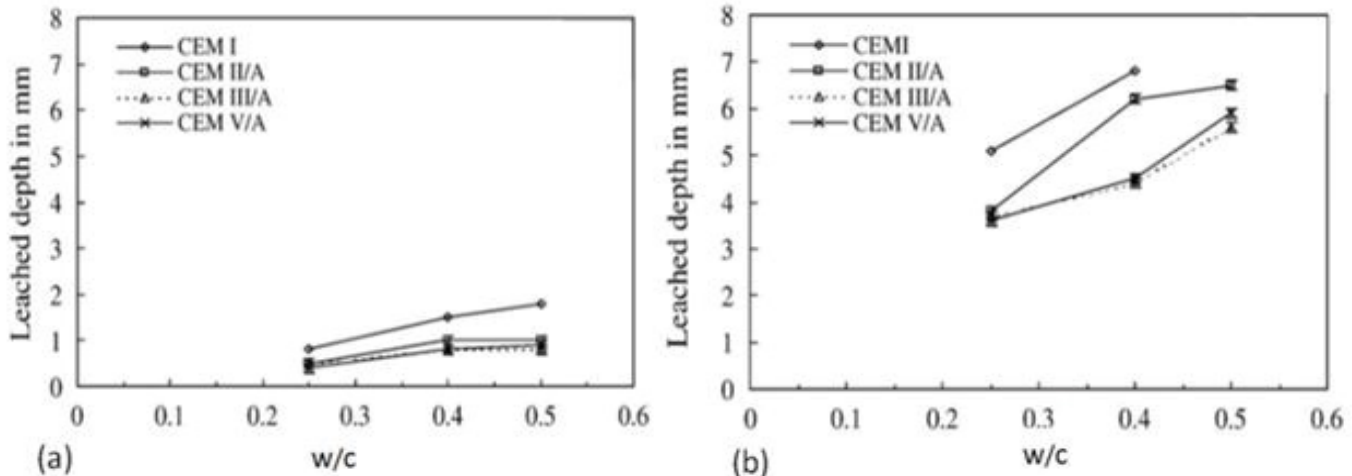

Figure 4: Leached depth of various cements degraded in; 4a) pure water at $26^{\circ} \mathrm{C}$ for 114 days, (4b) ammonium nitrate at $20^{\circ} \mathrm{C}$ for 19 days [20]

When concrete early exposed to aggressive solution, the pozzolan cement might be deteriorated signifi- cantly higher than OPC. Choi and Yang [10] found that the loss of strength in the concrete blend with the mineral admixture was larger than the non-replacement result, because the leaching speed was faster than the pozzolanic reaction. However, the anticipated leaching resistance can be achieved when the structure is exposed to aggressive solution after substantial completion of the pozzolanic reaction.

\section{Relationships sorptivity and permeability}

Strong correlation between sorptivity and permeability as the order of the variation in the concrete prop- erties showed similar trend when subjected to variables like, cement types and curing period [22]. Dinku and Reinhardt [23], and Lampacher and Blight [24] found that sorptivity increases as gas permeability increases as shown in Figure 6. The strength of correlation for OPC and blended cement may decrease at long age. This is because Carbonation reaction takes place in OPC-concrete, which results in decreasing capillary porosity and sorptivity, but gas permeability keeps similar trend for poz-zolan and OPC [24]. However, carbonation risk is less for water retaining struc- tures. Carbonation is most rapid when the relative humidity is in the region of $50-60 \%$ [15]. Therefore, as long as risk of carbonation is less, the strong relation between sorptivity and permeability will exist even for mature concrete.
Based on either sorptivity or permeability test result, the durability of concrete can be determined. The pressure applied for water permeability test does not represent actual site exposure and the pressure may break some weak aggregates. Moreover, water permeability test is less suitable than sorptivity due to the fact that it is difficult to test many specimens' permeability at a time, and specimens cannot be reused for other test due to destructive nature of permeability test.

\section{Experimental Methodology}

The experiment consists of three types of testing: compressive strength, sorptivity, and leaching tests. All of the test specimens were casted in standard cubes of size $150 \times 150 \times 150 \mathrm{~mm}$, a compressive strength of $30 \mathrm{MPa}$, maximum aggregate size of $20 \mathrm{~mm}$, and slump of $30-60 \mathrm{~mm}$. The basis for strength and material specification of this experiment is based on the specifications used for RC water tanks employed in Ethiopia.

The first experiment involved testing of a total of 18 specimens at the ages of 3,7 , and 28 days for compressive strength. The compressive strength of concrete was determined by testing the cubes in a compression-testing machine at a rate of $6.8 \mathrm{MPa} / \mathrm{s}$. The types of cement were OPC and PPC and the specimens were kept in water submerged curing until their test dates. 


\begin{tabular}{|c|c|c|c|c|}
\hline \multirow{2}{*}{ Cement types } & \multicolumn{2}{|c|}{28 days } & \multicolumn{2}{c|}{90 days } \\
\cline { 2 - 5 } & Porosity (\%) & $\begin{array}{c}\text { Sorptivity } \\
\left(\mathbf{m m} / \mathbf{m}^{\mathbf{0 . 5}}\right)\end{array}$ & Porosity (\%) & $\begin{array}{c}\text { Sorptivity (mm/ } \\
\left.\mathbf{m}^{\mathbf{0 . 5}}\right)\end{array}$ \\
\hline CEM I & 13.21 & 0.122 & 13.11 & 0.102 \\
\hline CEM IV & 15.51 & 0.139 & 15.74 & 0.097 \\
\hline
\end{tabular}

Table 1: Porosity and sorptivity of mortar of pozzolanic cement (CEM IV) and OPC (CEM I) for w/c ratio of 0.425 [7].

\begin{tabular}{|c|c|}
\hline Type of cement used for concrete & Curing period \\
\hline ASTM C 150 Type I & 7 days \\
\hline ASTM C 150 Type II & 10 days \\
\hline ASTM C 150 Type III & 3 days \\
\hline ASTM C 150 Type IV or Type V cement & 14 days \\
\hline $\begin{array}{c}\text { Blended cement in various proportion as ASTM C595, } \\
\text { C 854, and C 1157 }\end{array}$ & Variable \\
\hline
\end{tabular}

Table 2: Recommended minimum duration of concrete curing [17]

The second experiment involved testing of a total of 36 specimens for sorptivity at age of 29,58 , and 98 days. The first 18 specimens were made from OPC cement, and the next 18 were from PPC. The specimens were submerged in water tank for age of $(3,10$, and 28 days), then kept outside laboratory under natural conditions until the test date. The sorptivity test was conducted at age of 29 days for the first 18 cubes. The next 18 cubes were tested for sorptivity at age of 58 , and 98 days.

The third experiment involved testing of 12 specimens, out of 18 specimens that were previously used for sorptivity test at age of $29^{\text {th }}$ day, for leaching resistance at age of $48^{\text {th }}$ day. After leaching test, compressive strength of the specimens was measured at age of $63^{\text {th }}$ day.

\section{Material preparation and specimen casting}

The materials used for the production of concrete test specimens were Portland cement, natural/river sand, gravel, and tap water. All aggregates were ensured to be free from deleterious substances such as organic impurities, clay, and other unsound particles. The fine aggregate was natural sand with a fineness modulus of 2.81 , a saturated surface dry specific gravity of 2.76 and water absorption of $3.31 \%$. Crushed stone with a maximum nominal size of $20 \mathrm{~mm}$ and a saturated surface dry specific gravity of 2.70 was used.

The mix proportioning of materials was based on DOE method of concrete mix design [25]. OPC and PPC cement were used for mix A and mix B, respectively for C-30 concrete as presented in Table 3 . Both mixes were used cement: Mix A, OPC 42.5R; and MIX B, PPC 32.5R which produced in Mossobo, Ethiopia.

\section{Sorptivity test}

Rate of water absorption (sorptivity) is a good parameter to measure quality of concrete [26], and it can be used for an estimate of the service life of concrete exposed permanently to water [8,27]. It is also a good indicator of curing extent in concrete $[18,23]$.

Sorptivity testing was performed based on ASTM-C1585-04 subjected to some modification. The test equipment used to allow capillary absorption of water in concrete specimen was a rectangular metal pan as shown in Figure 7. The rate of absorption of water is calculated as follows:

$$
S=\frac{\Delta m}{A \rho \sqrt{t}}
$$

Where, $\mathrm{S}$ is sorptivity $\left(\mathrm{g} / \mathrm{m}^{2} \mathrm{~s}^{0.5}\right), \Delta_{\mathrm{m}}$ is change in mass $(\mathrm{g}), \mathrm{A}$ is area in contact with water $\left(\mathrm{m}^{2}\right), \rho$ is density of water $\left(\mathrm{g} / \mathrm{mm}^{3}\right)$, and $\mathrm{t}$ is time $(\mathrm{s})$.
In order to ensure unidirectional flow, the specimens were coated epoxy on vertical sides. The specimens were placed over wire mesh support to allow water contact with bottom surface of specimen, and then the pan was gently filled with tap water until it reached a level approximately 1 to $3 \mathrm{~mm}$ above the level of the exposed surface. Next, $300 \mathrm{gm}$ of cement was added to ensure the lime saturation in the water. In order to allow equal degree of lime saturation in the subsequent tests, the pan and specimen-supporting mesh were washed after each test had completed.

To determine the $29^{\text {th }}, 58^{\text {th }}$ and $98^{\text {th }}$ days sorptivity, the specimens were weighed at $0.5,1$, and 6 hours, and $1,2,3,4,5,6,7$ and 8 days. Then, the effects of independent variables (cement type, curing period, and test age) on sorptivity (dependent variable), and interaction between independent variables were analyzed in a statistical model (ANOVA) using software named "Stata/SE 12".

\section{Acid attack test}

Although there has not been standardized test for leaching, the deterioration of concrete can be deter- mined by exposing to strong acids. The mass change of a specimen is a widely used indicator for com-paring the deterioration of concrete exposed to aggressive liquid [21].

The leaching pan was a plastic made material with a capacity to hold six cubes at a time. After initial weight was measured, the specimens were placed over the crushed stone support with a size approximately below $10 \mathrm{~mm}$ to ensure acid contact with bottom surface of specimens. Next, the pan was gently filled with sulfuric acid with concentration of $98 \%$ ( $\mathrm{pH}$ of 0.1 ) until it reached a level approximately $40 \mathrm{~mm}$ above the level of the exposed surface, and finally the pan was covered on top.

The specimens were removed from the pan at $8^{\text {th }}$ and $14^{\text {th }}$ days for weighing. Prior to weighing, the specimens were rinsed by tape water to remove loose reaction products, and to prevent possible harm. Next, after being air-dried for 5 minutes, the specimens were weighed. The weight loss due to acid leaching during immersion to sulfuric acid can be calculated for as follows:

$$
M_{L S}=\frac{M_{I}-M_{F}}{M_{I}} \times 100
$$

Where $M_{L S}$ is mass loss during exposure to sulfuric acid (\%), $M_{I}$ is initial mass before exposure to sulfuric acid $(\mathrm{kg})$, and $\mathrm{M}_{\mathrm{F}}$ is final mass after exposure to sulfuric acid $(\mathrm{kg})$.

\section{Results and Discussion}

\section{The compressive strength test results}

The strength development of both concrete was illustrated graphically in Figure 8. The strength of OPC concretes were $18.2 \mathrm{MPa}$ at age of $3^{\text {rd }}$ day, $26.7 \mathrm{MPa}$ at age of $7^{\text {th }}$ day, and $38.2 \mathrm{MPa}$ at age of $28^{\text {th }}$ day, while PPC concretes were 16.7, 24.1, and 31.6 MPa for corresponding ages.

Concrete mix with OPC exhibited larger rate of strength gain between 3, 7, and 28 days' compressive strength test than PPC. The variations were $1.5 \mathrm{MPa}$ at $3^{\text {rd }}$ day, $2.6 \mathrm{MPa}$ at $7^{\text {th }}$ day, and $6.6 \mathrm{MPa}$ at $28^{\text {th }}$ day, showing an increase at increasing rate from 3 to 28 days. This confirms that OPC cement has higher strength gain speed than PPC cement due to faster rate of hydration.

The compressive strength graph showed best fit for logarithm model with a coefficients of determination $\left(\mathrm{R}^{2}\right)$ above 0.98 for both cements. This is in line with graphical model produced to determine useful curing period as made by Devillers et al. [18]. OPC had satisfied the 
Citation: Tsegaye M, Dinku A (2018) Effects of Curing and Cement Type on Leak deterioration of Concrete in Water Tanks. J Civil Environ Eng 8: 322. doi: 10.4172/2165$784 X .1000322$

Page 5 of 9

\begin{tabular}{|c|c|c|c|c|c|c|c|c|}
\hline Mixture & $\begin{array}{c}\text { Strength class } \\
(\mathbf{m P a})\end{array}$ & Slump $(\mathbf{m m})$ & $\mathbf{W} / \mathbf{C}$ & $\begin{array}{c}\text { Water } \mathbf{( k g} / \\
\mathbf{m}^{\mathbf{3}} \mathbf{)}\end{array}$ & $\begin{array}{c}\text { Cement } \mathbf{( k g} / \\
\left.\mathbf{m}^{\mathbf{3}}\right)\end{array}$ & $\begin{array}{c}\text { Coarse aggregate } \mathbf{( k g} / \\
\left.\mathbf{m}^{\mathbf{3}}\right)\end{array}$ & $\begin{array}{c}\text { Fine aggregate } \mathbf{( k g} / \\
\left.\mathbf{m}^{\mathbf{3}}\right)\end{array}$ & Cement type \\
\hline Mix A & 30 & $30-60$ & 0.53 & 190 & 360 & 1165 & 715 & OPC (CEM-I) \\
\hline Mix B & 30 & $30-60$ & 0.53 & 190 & 360 & 1165 & 715 & PPC (CEM-II) \\
\hline
\end{tabular}

Table 3: Concrete mixture designs.

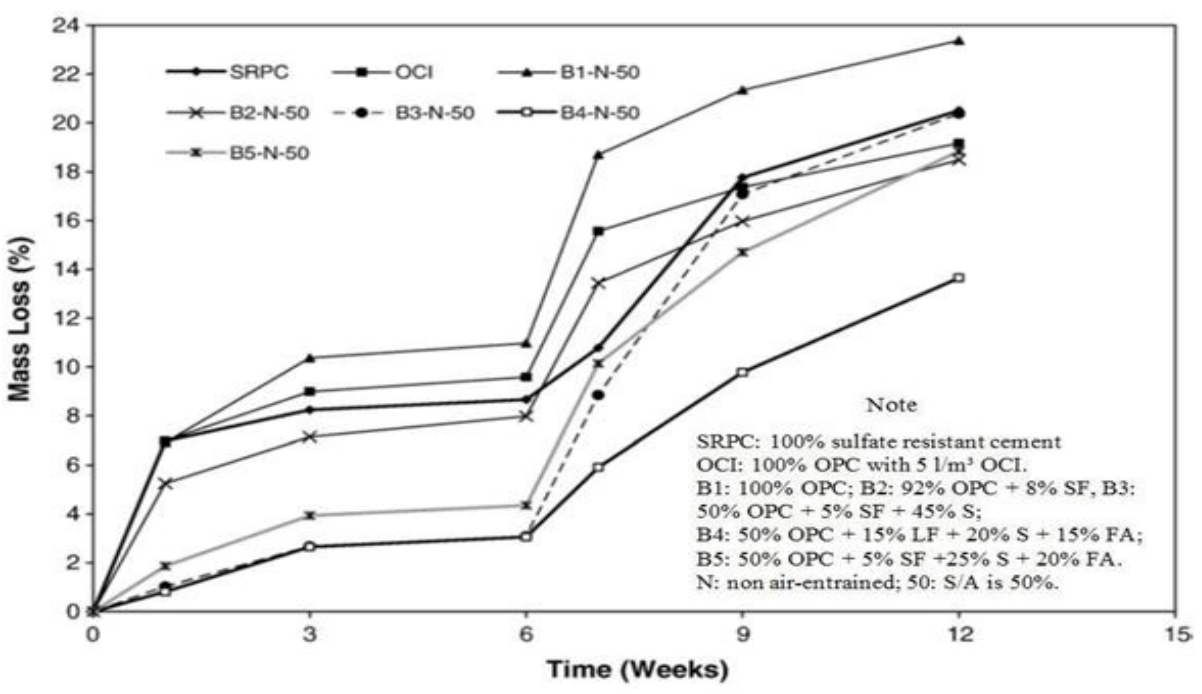

Figure 5: Mass loss of concrete mad in various types of cements in sulfuric acid immersion after 56 days cured [21].
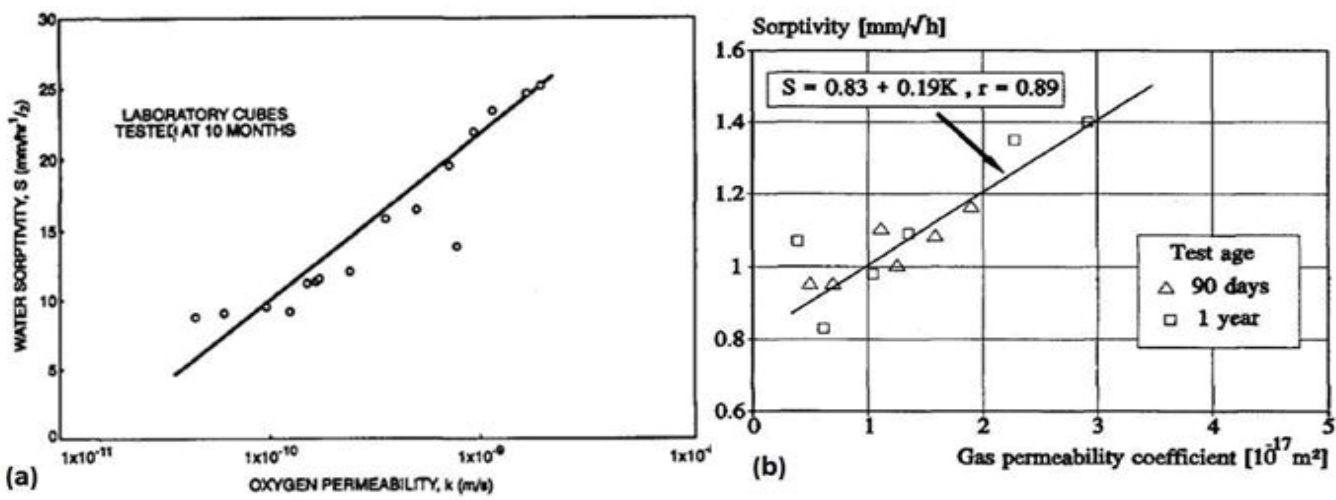

Figure 6: (a) Permeability and sorptivity of young concrete [24]; (b) Sorptivity and gas permeability [23].

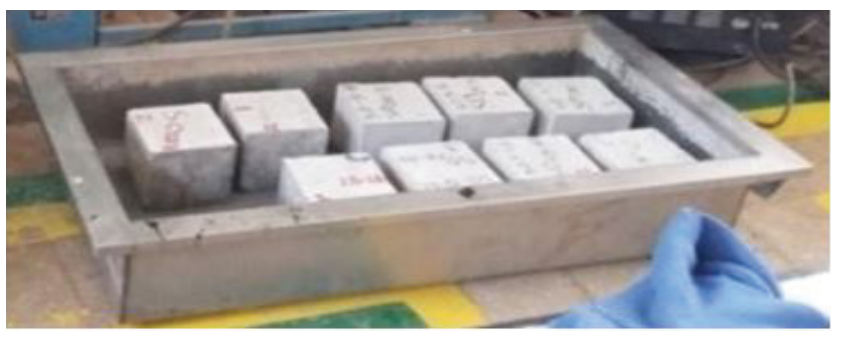

Figure 7: Specimens inside equipment to allow water absorption.

$70 \%$ strength criteria at age of 7 days, and it conforms to ACI curing recommendation while PPC could not. Therefore, upon interpolation from the model, the concrete specimen made with PPC cement needs minimum 14 days curing period to achieve $70 \%$ of the $28^{\text {th }}$ day design compressive strength. The interpolated period had not conformed to curing recommendations of ACI-308R for ASTM C150 TYPE II, rather it had conformed nearly to ASTM C150 Type IV, or Type V that prescribes a minimum of 14 days. Therefore, although Messobo PPC is categorized under ASTM C150 TYPE II cement, the specified 10-day curing by ACI-308R is not sufficient in this case.

Therefore, application of higher content of PPC than OPC to comply with 7-day strength criteria leads to wrong decision when PPC cement is used for RC storage structures. Because if concrete with higher content of pozolana cement is left dry after 7 days wet-curing, the required moisture will evaporate though the specimen meets the $70 \%$ strength criteria. As a result, the concrete would fail to meet the required durability. 
Citation: Tsegaye M, Dinku A (2018) Effects of Curing and Cement Type on Leak deterioration of Concrete in Water Tanks. J Civil Environ Eng 8: 322. doi: 10.4172/2165$784 X .1000322$

Page 6 of 9

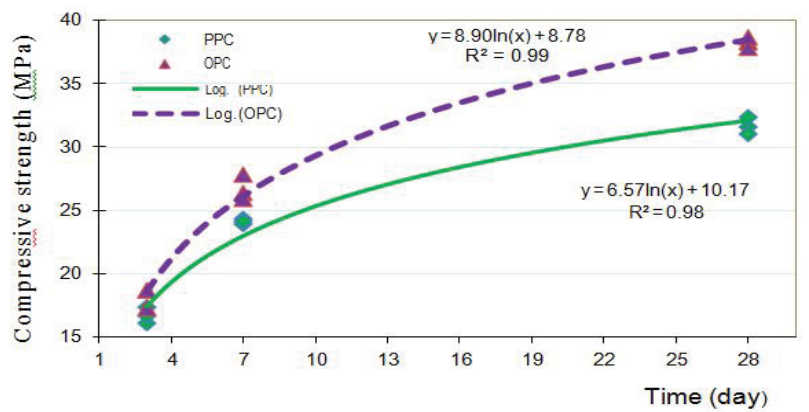

Figure 8: Compressive strength of concrete at age of 3,7 , and 28 days.

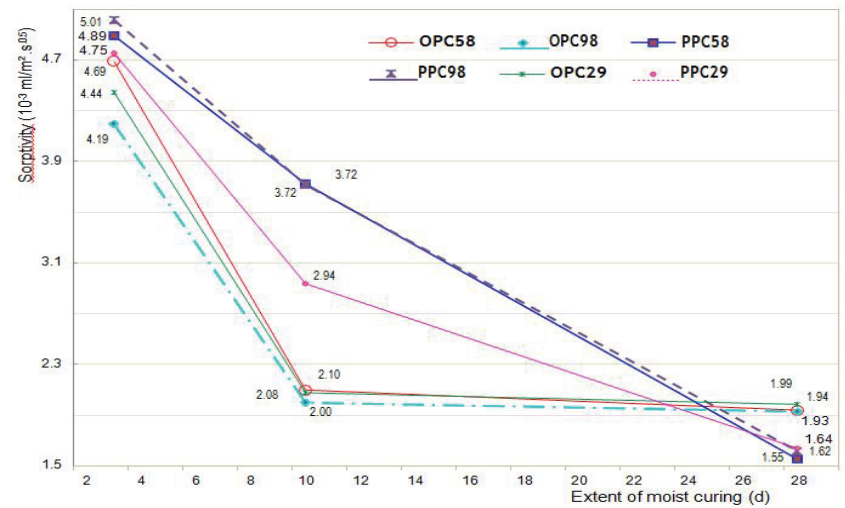

Figure 9: The 6th day sorptivity of concrete made using OPC and PPC cements for different curing period.

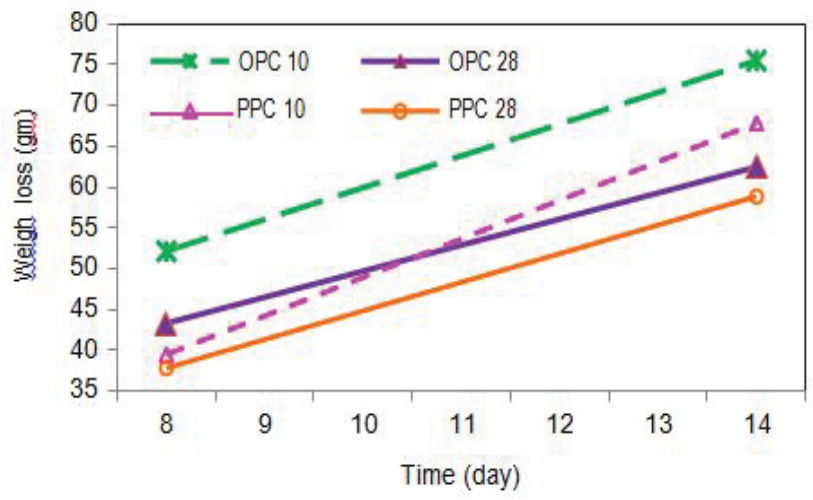

Figure 10: Weight loss by sulfuric acid for concrete in OPC and PPC at the age of 48 days

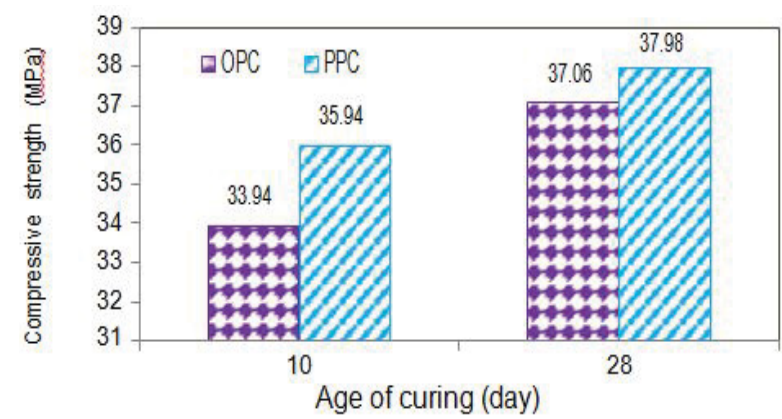

Figure 11: The 63th day strength of OPC and PPC after immersed in sulfuric acid.

\begin{tabular}{|c|c|c|c|}
\hline \multirow{2}{*}{ Variables } & \multicolumn{3}{|c|}{ Test ages } \\
\cline { 2 - 4 } & $\mathbf{2 9 d}$ & $\mathbf{5 8 d}$ & $\mathbf{9 8 d}$ \\
\hline \multirow{2}{*}{ Curing period (1) } & $0.253^{* *}$ & $0.295^{* * *}$ & $0.264^{* * *}$ \\
\cline { 2 - 4 } & -0.0939 & -0.0752 & -0.0824 \\
\hline \multirow{2}{*}{ Curing period (2) } & -0.0209 & -0.0627 & -0.0227 \\
\cline { 2 - 4 } & -0.0939 & -0.0752 & -0.0824 \\
\hline \multirow{2}{*}{ Cement type (1) } & 0.102 & $0.181^{* *}$ & $0.177^{* *}$ \\
\hline \multirow{2}{*}{ Curing period (2) \# Cement type (1) } & -0.0939 & -0.0752 & -0.0824 \\
\cline { 2 - 4 } & -0.165 & $-0.267^{* *}$ & $-0.255^{* *}$ \\
\hline Observations & -0.133 & -0.106 & -0.116 \\
\hline R-squared & 66 & 66 & 66 \\
\hline \multirow{2}{*}{ (1) } & 0.301 & 0.509 & 0.411 \\
\hline
\end{tabular}

Standard errors in parentheses, ${ }^{* * *} p<0.01,{ }^{* *} p<0.05,{ }^{*} p<0.1$

Coding: Cement type $(O P C=0, P P C=1)$; Curing period $(10 d=0,3 d=1$, and $28 \mathrm{~d}=2)$; (\# = interaction)

Table 4: Effects of curing period, cement types and their interaction effect on sorptivity $\left(10^{-3} \mathrm{ml} / \mathrm{m}^{2} . \mathrm{s}^{0.5}\right)$ of concrete.

\begin{tabular}{|c|c|c|c|c|c|c|c|c|c|c|c|}
\hline Specimen & \multicolumn{10}{|c|}{ Measurement time } \\
\cline { 2 - 12 } & $\begin{array}{c}\mathbf{0 . 5} \\
\mathbf{h r}\end{array}$ & $\mathbf{1} \mathbf{h r}$ & $\mathbf{6} \mathbf{h r}$ & $\mathbf{1} \mathbf{d}$ & $\mathbf{2} \mathbf{d}$ & $\mathbf{3} \mathbf{d}$ & $\mathbf{4} \mathbf{d}$ & $\mathbf{5} \mathbf{d}$ & $\mathbf{6} \mathbf{d}$ & $\mathbf{7} \mathbf{d}$ & $\mathbf{8} \mathbf{d}$ \\
\hline SO29-3 & 0.43 & 0.67 & 1.22 & 1.91 & 2.40 & 2.61 & 2.71 & 2.83 & 3.20 & 3.26 & 3.38 \\
\hline SO29-10 & 0.43 & 0.53 & 0.76 & 1.04 & 1.21 & 1.33 & 1.34 & 1.42 & 1.50 & 1.50 & 1.51 \\
\hline SO29-28 & 0.41 & 0.51 & 0.74 & 0.95 & 1.12 & 1.25 & 1.31 & 1.38 & 1.43 & 1.44 & 1.43 \\
\hline SP29-3 & 0.41 & 0.57 & 1.50 & 1.84 & 2.49 & 2.90 & 3.19 & 3.36 & 3.42 & 3.57 & 3.63 \\
\hline SP29-10 & 0.38 & 0.49 & 0.93 & 1.21 & 1.61 & 1.81 & 1.94 & 2.01 & 2.12 & 2.17 & 2.18 \\
\hline SP29-28 & 0.36 & 0.42 & 0.71 & 0.89 & 0.98 & 1.05 & 1.11 & 1.16 & 1.18 & 1.21 & 1.22 \\
\hline SO58-3 & 0.48 & 0.66 & 1.23 & 2.15 & 2.64 & 2.89 & 3.05 & 3.28 & 3.37 & 3.49 & 3.46 \\
\hline SO58-10 & 0.28 & 0.48 & 0.79 & 1.11 & 1.27 & 1.32 & 1.39 & 1.46 & 1.51 & 1.56 & 1.58 \\
\hline SO58-28 & 0.25 & 0.33 & 0.51 & 0.94 & 1.17 & 1.25 & 1.32 & 1.37 & 1.40 & 1.42 & 1.43 \\
\hline SP58-3 & 0.39 & 0.51 & 1.16 & 1.84 & 2.64 & 3.08 & 3.32 & 3.41 & 3.52 & 3.61 & 3.67 \\
\hline SP58-10 & 0.37 & 0.50 & 0.96 & 1.44 & 1.97 & 2.22 & 2.38 & 2.51 & 2.68 & 2.75 & 2.83 \\
\hline SP58-28 & 0.23 & 0.33 & 0.53 & 0.67 & 0.82 & 0.97 & 1.04 & 1.03 & 1.12 & 1.14 & 1.14 \\
\hline OPC98-3 & 0.46 & 0.64 & 1.12 & 2.00 & 2.40 & 2.64 & 2.76 & 2.85 & 3.02 & 3.11 & 3.16 \\
\hline OPC98-10 & 0.30 & 0.46 & 0.79 & 1.09 & 1.26 & 1.30 & 1.35 & 1.38 & 1.44 & 1.50 & 1.53 \\
\hline OPC98-28 & 0.34 & 0.43 & 0.66 & 0.96 & 1.18 & 1.24 & 1.33 & 1.35 & 1.39 & 1.42 & 1.42 \\
\hline PPC98-3 & 0.36 & 0.55 & 1.52 & 2.05 & 2.67 & 3.17 & 3.36 & 3.44 & 3.61 & 3.72 & 3.78 \\
\hline PPC98-10 & 0.25 & 0.51 & 0.93 & 1.53 & 1.93 & 2.29 & 2.39 & 2.53 & 2.68 & 2.77 & 2.81 \\
\hline PPC98-28 & 0.22 & 0.45 & 0.66 & 0.80 & 0.92 & 1.00 & 1.08 & 1.13 & 1.16 & 1.18 & 1.18 \\
\hline
\end{tabular}

Table 5: Summary of Sorptivity $\left(\mathrm{g} / \mathrm{m}^{2}\right)$ at age of 29,58 , and 98 days.

\section{The sorptivity test results}

The summarized test results of sorptivity are presented in Figure 9 and Table 4. In addition to, detailed test results that used for statistical analysis are annexed in Tables 5 and 6 . The variations among three measurements of sorptivity $\left(10^{-3} \mathrm{ml} / \mathrm{m}^{2} . \mathrm{s}^{0.5}\right)$ were mostly within $6 \%$, and their correlation coefficient $\left(\mathrm{R}^{2}\right)$ were 0.97 and above.

Figure 9 shows that the sorptivity of 3-day cured OPC-concrete significantly exceeds the 10-day cured concrete by values of 2.59 (4.692.10 ) and 2.19 at test ages of $58^{\text {th }}$ and $98^{\text {th }}$ days, respectively, whereas the 10-day cured OPC-concrete exceeds the 28 -day cured by 0.16 and 0.07 at test ages of 58 and 98 days, respectively. Conversely, the sorptivity of 10-day cured PPC-concrete significantly exceeds the 28-day cured specimens by values of 2.17 and 2.10 at test ages of $58^{\text {th }}$ and $98^{\text {th }}$ days, respectively. Whereas the sorptivity of 3-day cured PPC-concrete significantly exceeds the 10-day cured concrete by values of 1.17 and 1.29 at test ages of $58^{\text {th }}$ and $98^{\text {th }}$ days, respectively. The lower variation between 3-day and10- day cured PPC-concrete was resulted from lower rate of reaction of pozzolans [7].

For 10-day cured specimens, PPC showed higher sorptivity value than OPC, exceeding by 1.62 and 1.64 at test ages of $58^{\text {th }}$ and $98^{\text {th }}$ 
Citation: Tsegaye M, Dinku A (2018) Effects of Curing and Cement Type on Leak deterioration of Concrete in Water Tanks. J Civil Environ Eng 8: 322. doi: 10.4172/2165$784 X .1000322$

Page 7 of 9

\begin{tabular}{|c|c|c|c|c|c|c|c|c|c|}
\hline$S_{L}$ & Curing duration & Cement type & Test age & Read time & $S_{L}$ & Curing duration & Cement type & Test age & Read time \\
\hline 1.01 & 1 & 0 & 2 & 0 & 0.99 & 1 & 1 & 2 & 0 \\
\hline 1.05 & 1 & 0 & 2 & 1 & 0.98 & 1 & 1 & 2 & 1 \\
\hline 0.92 & 1 & 0 & 2 & 2 & 1.01 & 1 & 1 & 2 & 2 \\
\hline 0.81 & 1 & 0 & 2 & 3 & 0.80 & 1 & 1 & 2 & 3 \\
\hline 0.76 & 1 & 0 & 2 & 4 & 0.78 & 1 & 1 & 2 & 4 \\
\hline 0.71 & 1 & 0 & 2 & 5 & 0.76 & 1 & 1 & 2 & 5 \\
\hline 0.66 & 1 & 0 & 2 & 6 & 0.73 & 1 & 1 & 2 & 6 \\
\hline 0.63 & 1 & 0 & 2 & 7 & 0.71 & 1 & 1 & 2 & 7 \\
\hline 0.65 & 1 & 0 & 2 & 8 & 0.68 & 1 & 1 & 2 & 8 \\
\hline 0.62 & 1 & 0 & 2 & 9 & 0.66 & 1 & 1 & 2 & 9 \\
\hline 0.61 & 1 & 0 & 2 & 10 & 0.64 & 1 & 1 & 2 & 10 \\
\hline 1.00 & 0 & 0 & 2 & 0 & 0.95 & 0 & 1 & 2 & 0 \\
\hline 0.95 & 0 & 0 & 2 & 1 & 0.91 & 0 & 1 & 2 & 1 \\
\hline 0.71 & 0 & 0 & 2 & 2 & 0.80 & 0 & 1 & 2 & 2 \\
\hline 0.55 & 0 & 0 & 2 & 3 & 0.62 & 0 & 1 & 2 & 3 \\
\hline 0.46 & 0 & 0 & 2 & 4 & 0.59 & 0 & 1 & 2 & 4 \\
\hline 0.42 & 0 & 0 & 2 & 5 & 0.55 & 0 & 1 & 2 & 5 \\
\hline 0.36 & 0 & 0 & 2 & 6 & 0.52 & 0 & 1 & 2 & 6 \\
\hline 0.33 & 0 & 0 & 2 & 7 & 0.49 & 0 & 1 & 2 & 7 \\
\hline 0.32 & 0 & 0 & 2 & 8 & 0.47 & 0 & 1 & 2 & 8 \\
\hline 0.29 & 0 & 0 & 2 & 9 & 0.45 & 0 & 1 & 2 & 9 \\
\hline 0.26 & 0 & 0 & 2 & 10 & 0.42 & 0 & 1 & 2 & 10 \\
\hline 0.98 & 2 & 0 & 2 & 0 & 0.93 & 2 & 1 & 2 & 0 \\
\hline 0.93 & 2 & 0 & 2 & 1 & 0.85 & 2 & 1 & 2 & 1 \\
\hline 0.70 & 2 & 0 & 2 & 2 & 0.68 & 2 & 1 & 2 & 2 \\
\hline 0.51 & 2 & 0 & 2 & 3 & 0.48 & 2 & 1 & 2 & 3 \\
\hline 0.43 & 2 & 0 & 2 & 4 & 0.37 & 2 & 1 & 2 & 4 \\
\hline 0.39 & 2 & 0 & 2 & 5 & 0.31 & 2 & 1 & 2 & 5 \\
\hline 0.35 & 2 & 0 & 2 & 6 & 0.28 & 2 & 1 & 2 & 6 \\
\hline 0.32 & 2 & 0 & 2 & 7 & 0.25 & 2 & 1 & 2 & 7 \\
\hline 0.30 & 2 & 0 & 2 & 8 & 0.21 & 2 & 1 & 2 & 8 \\
\hline 0.27 & 2 & 0 & 2 & 9 & 0.19 & 2 & 1 & 2 & 9 \\
\hline 0.24 & 2 & 0 & 2 & 10 & 0.17 & 2 & 1 & 2 & 10 \\
\hline 1.05 & 1 & 0 & 1 & 0 & 0.96 & 1 & 1 & 1 & 0 \\
\hline 1.04 & 1 & 0 & 1 & 1 & 0.93 & 1 & 1 & 1 & 1 \\
\hline 0.92 & 1 & 0 & 1 & 2 & 0.90 & 1 & 1 & 1 & 2 \\
\hline 0.86 & 1 & 0 & 1 & 3 & 0.80 & 1 & 1 & 1 & 3 \\
\hline 0.80 & 1 & 0 & 1 & 4 & 0.80 & 1 & 1 & 1 & 4 \\
\hline 0.75 & 1 & 0 & 1 & 5 & 0.78 & 1 & 1 & 1 & 5 \\
\hline 0.72 & 1 & 0 & 1 & 6 & 0.75 & 1 & 1 & 1 & 6 \\
\hline 0.70 & 1 & 0 & 1 & 7 & 0.72 & 1 & 1 & 1 & 7 \\
\hline 0.67 & 1 & 0 & 1 & 8 & 0.69 & 1 & 1 & 1 & 8 \\
\hline 0.65 & 1 & 0 & 1 & 9 & 0.67 & 1 & 1 & 1 & 9 \\
\hline 0.62 & 1 & 0 & 1 & 10 & 0.65 & 1 & 1 & 1 & 10 \\
\hline 0.82 & 0 & 0 & 1 & 0 & 0.94 & 0 & 1 & 1 & 0 \\
\hline 0.90 & 0 & 0 & 1 & 1 & 0.92 & 0 & 1 & 1 & 1 \\
\hline 0.73 & 0 & 0 & 1 & 2 & 0.82 & 0 & 1 & 1 & 2 \\
\hline 0.58 & 0 & 0 & 1 & 3 & 0.69 & 0 & 1 & 1 & 3 \\
\hline 0.48 & 0 & 0 & 1 & 4 & 0.68 & 0 & 1 & 1 & 4 \\
\hline 0.41 & 0 & 0 & 1 & 5 & 0.64 & 0 & 1 & 1 & 5 \\
\hline 0.37 & 0 & 0 & 1 & 6 & 0.61 & 0 & 1 & 1 & 6 \\
\hline 0.35 & 0 & 0 & 1 & 7 & 0.58 & 0 & 1 & 1 & 7 \\
\hline 0.32 & 0 & 0 & 1 & 8 & 0.57 & 0 & 1 & 1 & 8 \\
\hline 0.30 & 0 & 0 & 1 & 9 & 0.55 & 0 & 1 & 1 & 9 \\
\hline 0.28 & 0 & 0 & 1 & 10 & 0.53 & 0 & 1 & 1 & 10 \\
\hline 0.77 & 2 & 0 & 1 & 0 & 0.73 & 2 & 1 & 1 & 0 \\
\hline 0.74 & 2 & 0 & 1 & 1 & 0.74 & 2 & 1 & 1 & 1 \\
\hline 0.54 & 2 & 0 & 1 & 2 & 0.56 & 2 & 1 & 1 & 2 \\
\hline 0.51 & 2 & 0 & 1 & 3 & 0.36 & 2 & 1 & 1 & 3 \\
\hline 0.45 & 2 & 0 & 1 & 4 & 0.29 & 2 & 1 & 1 & 4 \\
\hline
\end{tabular}




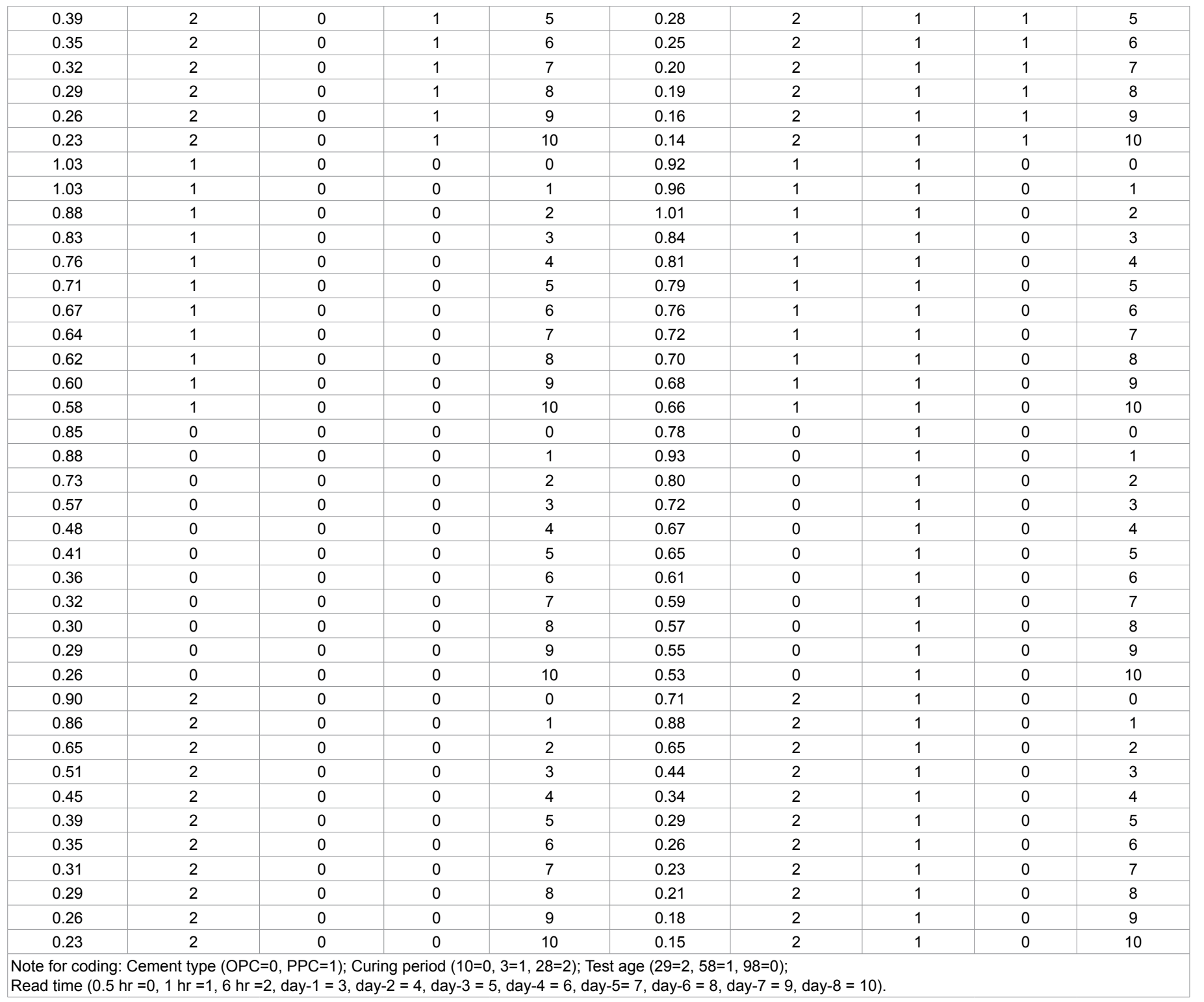

days, respectively. Whereas lower sorptivity values were measured in PPC than OPC for 28 days cured specimens, and variations were 0.39 and 0.31 at test ages of $58^{\text {th }}$ and $98^{\text {th }}$ days, respectively. The reason for higher variations of sorptivity for the 10-day cured concrete could have attributed due to the fact that OPC-concrete had been undergone substantial capillary segmentation during early ages (10-days), whereas most capillary segmentations of PPC-concrete had not been undergone during early ages (10-days) due slow rate of hydration and due to evaporation of required water when it left dry after 10-day curing. This argues with principle that if the moisture in the outer surface of concrete evaporates before sufficient hydration takes place, the open pore volume for transport of fluid increases $[18,19]$.

Table 4 shows the significance of independent variables and their interaction effect on sorptivity of concrete. The lowest curing period (3-day) increases sorptivity of concrete with $99 \%$ confidence level $(0.01$ significance), while the highest curing period (28-day) insignificantly reduces sorptivity of con- crete with respect to the 10-day curing for both cement types. Further, the 28-day curing period signifi- cantly (at 95\% confidence level) reduces sorptivity of PPC than OPC at test ages of $58^{\text {th }}$ and $98^{\text {th }}$ days with respect to the 10 -day curing. Therefore, when PPC-concrete is insufficient cured, only 10-day, it exhibits lower durability performance than OPC, whereas well cured PPC-concrete exhibits higher dura performance at ages of 2 months and above.

\section{Acid attack test results}

The relation between weight losses against immersion period is indicated in Figure 10. After 14 days of exposure, the concrete specimens made with OPC cement and subjected to 10 and 28 days curing period had the higher mass loss of $0.91 \%$ and $0.74 \%$, respectively, whereas specimens made with PPC cement and subjected to 10 and 28 days curing had lower corresponding mass loss of $0.78 \%$ and $0.67 \%$. The concrete made using OPC cement exhibited higher weight loss than PPC, and results were in line with the literatures [21]. Therefore, the study has revealed that the rate of attack is controlled by cement type and extent of curing. Furthermore, the compressive strength of PPC was found slightly higher than OPC cement at age of 63 days as shown in Figure 11 
Citation: Tsegaye M, Dinku A (2018) Effects of Curing and Cement Type on Leak deterioration of Concrete in Water Tanks. J Civil Environ Eng 8: 322. doi: 10.4172/2165$784 X .1000322$

\section{Conclusion and Recommendations}

\section{Conclusion}

The sorptivity of PPC-concrete was higher than OPC at early age, at $30^{\text {th }}$ day. However, well-cured PPC- concrete can exhibit lower sorptivity than OPC at later ages, 2 months and above. Conversely, higher sorptivity values were found for PPC-concrete than OPC when the concrete specimens are being cured only 10 days. Therefore, when 10-day cured PPC-concrete is used for RC water tank, sorptivity can have significant influence on transport water from surface being in contact with water into drying face result- ing in premature-deterioration of concrete. Because the level of water in RC concrete wall is frequentfluctuated due to domestic consumption resulting a partially saturated and/or dry concrete wall, thus water transport by capillary action occurs. Further, when concrete is exposed to aggressive environment at later ages, above 2 months and above, both compressive strength and leaching resistance of OPC- concrete were lower than PPC. Therefore, application of OPC-concrete in RC water tanks can be a cause for premature-deterioration of concrete.

\section{Recommendation/Further Study}

There are clearly significant benefits which can be achieved using $\mathrm{PPC}$-concrete for $\mathrm{RC}$ water storage tanks with regard to leak tightness. Further study should be carried out to investigate the influences of curing period and cement types on the sorptivity of concrete under controlled environment ( $\mathrm{pH}$ and relative humidity). In addition to, it is recommended to perform repetitive sorptivity tests on specimens at several ages. As sorptivity test is non-destructive test, repeated test results of a specimen can give better information on quality of concrete.

\section{Acknowledgments}

The first Author would like to acknowledge Amhara Construction Design and Supervision Enterprise and Ethiopian Road Authority for the financial support of the work.

\section{References}

1. Kosmatka S, Kerkhoff B, Panarese W (2003) Design and control of concrete mixtures. (4th edn). Portland Cement Association. New York, USA.

2. Neville A (2002) Properties of concrete ( $4^{\text {th }}$ edn) Pearson Education, England, UK. p: 483.

3. ASTM C1585 (2004) Standard test method for measurement of rate of absorption of water by hydraulic- cement concretes. ASTM International.

4. Buenfeld NR, Shurafa Daoudi MT, McLoughlin IM (1997) Chloride transport due to wick action in con- crete: Chloride penetration into concrete. Nilsson LO , Ollivier JP (eds). Paris, RILEM, France: 315-324.

5. Fagerlund, G (2000) Leaching of concrete: The leaching process: extrapolation of deterioration: effect on the structural stability. Division of Building Materials (Report TVBM-3091), LTH, Lund University, Sweden.

6. Nilsson LO, Tang L (1996) Transport mechanisms in porous materials- An introduction to their basic laws and correlations. The modelling of microstructure and its potential for studying transport properties and durability. Jennings $\mathrm{H}$ (ed), Kropp J (ed), Scrivener KK (ed). NATO ASI Series (Series E: Applied Sciences) Springer, Dordrecht, The Netherlands 304: 289-311.

7. Massazza F (1998) Pozzolana and pozozolanic cements. Lea's chemistry of cement and concrete (4th edn), Elsevier, USA: 471-636.

8. Bentz D, Ehlen M, Ferraris C, Winpigler J (2002) Service life prediction based on sorptivity for highway concrete exposed to sulphate attack and freeze-thaw conditions. Department of Transport, Federal Highway Administration, Report No. FHWA-RD-01-162, National Institute of Standards and Technology (NIST), Washington, DC, USA.

9. Ekström T (2001) Leaching of concrete, experiments and modeling (Report). Division of building materials, Report TVBM-3090, Lund Institute of Technology, Sweden.

10. Choi YS, Yang El (2013) Effect of calcium leaching on the pore structure, strength, and chloride penetration resistance in concrete specimens. Nucl Eng Des 259: 126-136.

11. Bentz DP, Garboczi EJ (1992) Modeling the leaching of calcium hydroxide from cement paste: Effects on pore space percolation and diffusivity. Mater Struct 25: 523-533.

12. Anchor RD (1992) Design of liquid retaining concrete structures. (2nd edn) New York, McGraw-Hill, USA. p: 185.

13. Alexander M, Bertron A, De Belie N (2013) Performance of cement-based materials in aggressive aqueous environments. RILEM State-of-the-Art Reports, Dordrecht, Springer, The Netherlands.

14. Torrenti JM, Nguyen VH, Colina H, Maou F, Benboudjema F, et al. (2008) Coupling between leaching and creep of concrete. Cem Concr Res 38: 816821

15. Euro-International Committee for Concrete (CBE) (1997) Durable concrete structures design guide, ICE Virtual library Books, London, UK. p: 59.

16. Basheer L, Kropp J, Cleland DJ (2001) Assessment of the durability of concrete from its permeation properties: A review. Constr Build Mater 15: 93-103.

17. ACI 308R-01 (2008) Guide to curing concrete. ACI Manual of Concrete Practice $\mathrm{ACl}$, Farmington Hills, Michigan, USA.

18. Devillers $P$, Cussigh F, Bonnard V, Linger L (2008) A new method for determining the useful curing period. Creep, shrinkage and durability mechanics of concrete and concrete structures. (1st edn). Tanabe Ta, Sakata K, Mihashi H, Sato R, Maekawa K (eds), et al. London, CRC Press, UK. 2: 395-402.

19. Bamforth PB (1991) The water permeability of concrete and its relationship with strength. Mag Concrete Res 43: 233-241.

20. Kamali S, Moranville M, Leclercq S (2008) Material and environmenta parameter effects on the leaching of cement pastes: Experiments and modelling. Cem Concr Res 38: 575-585.

21. Bassuoni MT, Nehdi ML (2007) Resistance of self-consolidating concrete to sulfuric acid attack with consecutive $\mathrm{pH}$ reduction. Cem Concr Res 37: 10701084.

22. Ballim Y (1996) Permeability and sorptivity response of concretes to variations in early-age curing-implications for durability specifications. The modelling of microstructure and its potential for studying transport properties and durability. Jennings $\mathrm{H}$ (ed), Kropp J (ed), Scrivener K (ed). NATO ASI Series (Series E: Applied Sciences). Dordrecht, Springer, The Netherlands. 2: 351-360.

23. Dinku A, Reinhardt HW (1997) Gas permeability coefficient of cover concrete as a performance control. Mater Struct 30: 387-393.

24. Lampacher BJ, Blight GE (1998) Permeability and sorption properties of mature near-surface concrete. J Mater Civ Eng 10: 21-25.

25. Teychenné D, Franklin R, Erntroy H (1997) Design of normal concrete mixes DOE. (2nd edn) Marsh K Watford B (eds), London Constructions Research Communications.

26. Beushausen H, Luco FL (2016) Performance-based specifications and contro of concrete durability. RILEM State-of-the-Art Reports. Dordrecht, Springer, The Netherlands.

27. Fagerlund G (1996) Predicting the service-life of concrete exposed to frost action through a modeling of the water absorption process in the air pore system. The Modelling of Micro- structure and Its Potential for Studying Transport Properties and Durability. Jennings H, Kropp J, Scrivener K (eds) NATO ASI Series (Series E: Applied Sciences). Dordrecht, Springer, The Netherlands 304: 503-537. 